\title{
121. Shoot Formation in Calli Originated from Rice Embryo
}

\author{
By Shin Tamura \\ Faculty of Agriculture, Niigata University \\ (Comm. by Toshitaro MorinagA, M. J. A., June 12, 1968)
}

In recent five years several investigators have succeeded in the callus formation from the organized tissue of the monocotyledons. Yamada reported both the callus and organ formation using young flower bud of Lilium.10) Later, Yatazawa and Furuhashi established a technique of growing indefinitely callus derived from rice seedlings. ${ }^{11,12)}$ Maeda published several papers on the structure and growth of the callus originated from rice seedlings.4)-7) In this paper the author has attempted to induce the adventive shoot from the cultured callus of rice once de-differentiated and succeeded in the method to control the budding from the callus in vitro.

Nineteen varieties of rice including Japonica, Indica, and European type, were used as materials. Seeds sterilized with cationic soap solution and sodium hypochlorite were plated in 50 or 100 c.c. Ehlenmyer flasks containing the modified White's medium which contained mineral salts, sucrose $(20 \mathrm{~g} / \mathrm{l})$, thiamine hydrochloride $(0.4 \mathrm{mg} / 1)$, yeast extract $(5 \mathrm{~g} / \mathrm{l}), 2,4$-dichlorophenoxyacetic acid $(2 \mathrm{mg} / \mathrm{l})$ and agar $(8 \mathrm{~g} / \mathrm{l})$. Within 10 or 15 days in darkness at $26^{\circ} \mathrm{C}$, extensive callus outgrowth was observed from the germinated seeds. Then well-grown calli were carefully separated from the seedlings so as not to put any residual fragment of the original tissue, and transferred asceptically to other flasks containing the same medium. After four weeks the calli were again transferred to a fresh medium and were allowed to grow for further four weeks, and then they were transferred into organ-forming medium. Eight kinds of media were compared regarding the shoot formation from the calli. These media had composition with several different basal media and varying amounts of vitamins, auxins, kinin, adenine, and other organic substances including plant extracts.

Histological observation of sectioned materials under microscope revealed considerable differences among rice varieties as to the cell size, disposition of meristematic tissue, formation of granular structure or nodule and differentiation of tracheid, etc. However, a week or two after the transfer, a distinct pattern was observed in calli of several varieties displaying active anticlinal cell division in the 
peripheral zone and the increase of the surface area of the callus while neither active cell division nor marked increase in the volume of the cells was observed in deeper region of the callus. Then a number of indentations towards the inside of the callus were observed and adventive shoot apice were formed around the bottom of the indentations (Figs. 1, 2). In this case, however, the initially formed leaves showed quite abnormal appearance and did not develop

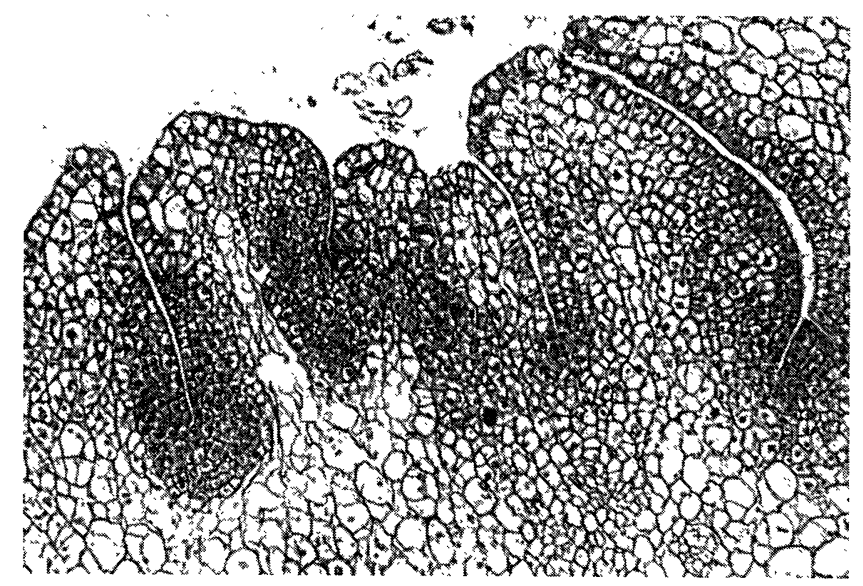

Fig. 1. Appearance of indentations on the callus surface at an early stage of differentiation.

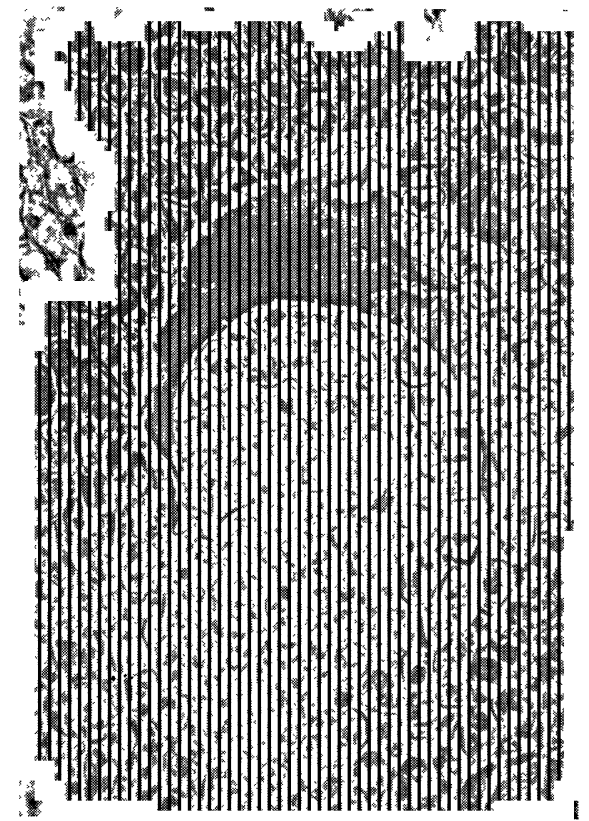

Fig. 2. Adventive shoot apex in the callus tissue.

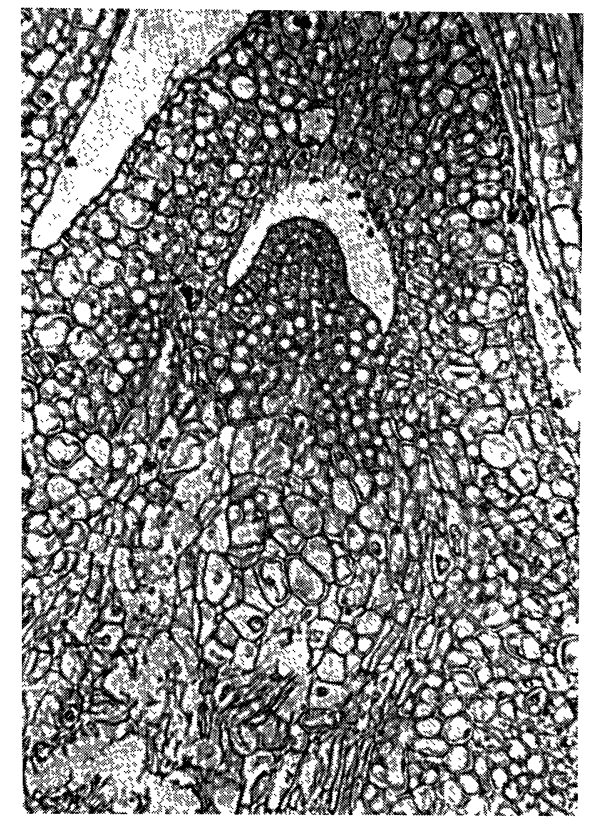

Fig. 3. Adventive shoot apex with abnormal leafy structure. 
further and remained shrunken (Fig. 3). Then normal leaf primordia were formed at the base of the apex which was surrounded by the abnormal leaves (Fig. 4), and developed into the normal leaves containing chlorophyl. Vasil and Hildebrandt reported the same observation on their experiment with Cichorium endivia.9)

Two weeks or more after incubation in light, many green buds were recognized macroscopically on the surface of the callus. Among eight media used, the most effective one had the following composition: Revised Linsmaier and Skoog's medium (RM-1964) containing thiamine hydrochloride $(0.4 \mathrm{mg} / \mathrm{l})$, mio-Inositol $(100 \mathrm{mg} / \mathrm{l})$, IAA $(2 \mathrm{mg} / \mathrm{l})$, kinetin $(4 \mathrm{mg} / \mathrm{l})$, sucrose $(20 \mathrm{~g} / 1)$ and agar $(8 \mathrm{~g} / 1)$. With this medium, the variety, "Noorin No. 11" showed $100 \%$ budding within 15 days after transfer. Other varieties which showed the high percentage of bud formation were "Noorin No. 15", "Rantajemas-1", "Jaguari", "Mitsudatsu", and "Kannon-sen", and the percentages of bud formation were $30,40,20,20$, and 50 respectively. Four varieties, "Noorin No.33", "Koshihibiki", "Lomello" and "Mitsudatsu" formed more buds when IAA content was reduced to $1 \mathrm{mg} / \mathrm{l}$ and kinetin content was raised up to $6 \mathrm{mg} / \mathrm{l}$. Regarding the organogenesis from undifferentiated callus Skoog and Miller reported that IAA/Kinetin ratio exerts the influence upon the kind oof rgan which was formed in the callus ${ }^{8}$ and Linsmaier and Skoog also reported that the high kinetin level was very favorable for bud formation from tabacco callus. ${ }^{3)}$ The present experiment indicated that there may be the difference among varieties of rice as to the optimal IAA/Kinetin ratio for bud formation from callus. Ishihara reported the formation of the adventive embryos on the surface of the callus of carrot tissue when the medium contained casein hydrolysate. ${ }^{1), 2)}$ However, in the present experi-

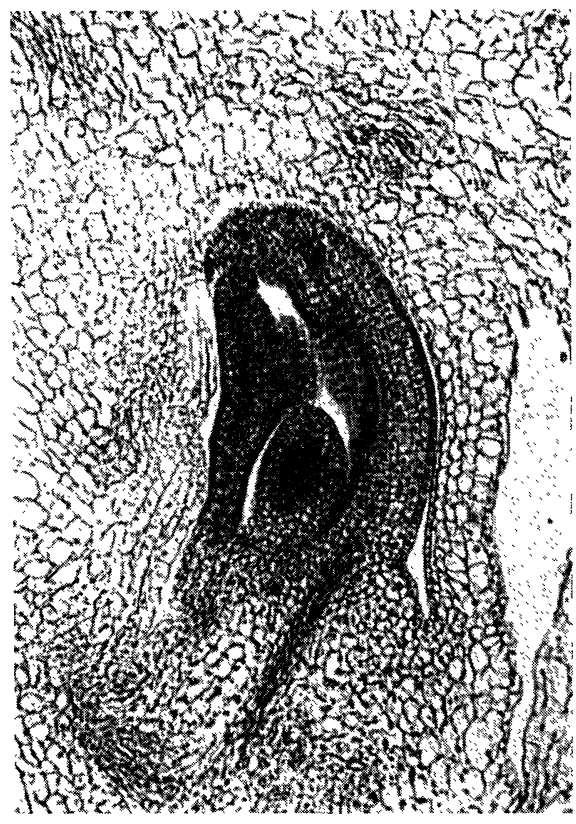

Fig. 4. Normal leaves formed from the adventive shoot apex. ment no adventive embryo has been found so far.

When visible buds grew and the second leaves extruded, they were separated from the callus and transplanted to other flasks 
containing the same basal medium in which IAA level was reduced to $0.2 \mathrm{mg} / 1$ and kinetin was omitted. After the plantlets formed adventitious roots and normally expanded four or five leaves they were transplanted again to the common china pot filled with fine sand and cultured with the Hoagland's nutrition solution. Growth appearance was almost identical as the plants which came from ordinary seeds, and developed the normal head and flower leading seed formation. These mature plants have shown normal character attributed to each rice variety. It seems, however, noteworthy that albino plants were formed in an exceedingly high frequency from the callus, but they ceased to grow after four or five leaves expanded and then browned and died. Whether such an appearance of albino plants is due to genetic factor or to physiological factor should be clarified in future work though the latter case seems to be plausible.

This is the first time that buds were formed in vitro from the callus originated from the embryos of the cereal crops and whole plants were cultivated from the buds. As the completely synthetic medium was used in this experiment, the result showed here leads to the possibility that one can artificially control the organogenesis of cereals. It will be expected that we may furnish important basic information as to the method of cultivating cereals if we can clarify the correlation between the ecological character and the organogenetic abilities of certain chemical factors among varieties of cereals. Furthermore this offers a beneficial technique for the breeding of cereals as to the proliferation of the haploid or mutant cells. The author wishes to express his appreciation to Professor N. Ogasawara for his helpful suggestions on the asceptic culture.

\section{References}

1) Ishihara, A.: On growth and organ formation of callus tissue in vitro originated from carrot roots. Proc. Crop Sci. Soc. Japan, 34, 225 (1965).

2) - : Histology and organogenesis in carrot callus tissue cultured in vitro. Proc. Crop Sci. Soc. Japan, 34, 431 (1966).

3) Linsmaier, E. M., and Skoog, F.: Organic growth factor requirements of tobacco tissue cultures. Physiol. Plant., 18, 100 (1965).

4) Maeda, E.: Callus formation and isolation of single cells from rice seedlings. Proc. Crop Sci. Soc. Japan, 34, 139 (1965).

5) - : Varietal difference in callus formation of rice seeds under sterile culture. Proc. Crop Sci. Soc. Japan, 36, 233 (1967).

6) - : Histology of asceptic callus tissues derived from rice embryos. Proc. Crop Sci. Soc. Japan, 36, 369 (1967).

7) - : Subculture and organ formation in the callus derived from rice embryos in vitro. Proc. Crop Sci. Soc. Japan, 37, 51 (1968).

8) Skoog, F., and Miller, C. O.: Chemical regulation of organ formation in plant tissues cultured in vitro. Symp. Soc. Exptl. Biol., 15, 118 (1957). 
9) Vasil, I. K., and Hildebrandt, A. C.: Variations of morphogenetic behavior in plant tissue cultures. I. Cichorium endivia. Amer. Jour. Bot., 53, 860 (1966).

10) Yamada, T.: Differentiation of roots and buds in flower tissues cultured in vitro. La Kromosomo, 55-56, 1858 (1963).

11) Yatazawa, M., and Furuhashi, K.: Indefinitely growing rice callus in tissue culture. Dojohiryogaku-zasshi, Supp., 11, Add., 18 (1965).

12) Yatazawa, M., Furuhashi, K., and Shimizu, M.: Growth of callus tissue from rice-root in vitro. Plant and Cell Physiology, 8, 363 (1967). 